\title{
Study of Mechanical and Surface Properties on some Chemical Treated Cotton Fabric by KES-F, SEM and FTIR Analysis
}

\section{Moses $\mathrm{JJ}^{1 *}$ and Venkataraman $\mathrm{VK}^{2}$}

${ }^{1}$ Department of Applied Science, PSG College of Technology, Coimbatore, India

${ }^{2}$ Department of Chemistry \& Applied Chemistry, PSG Polytechnic College, Coimbatore, India

\begin{abstract}
Chemical treatment of cellulosic fabrics to alter the fibers properties without changing their fibrous form is a common practice nowadays in the textile industry. In this paper cotton (woven and knitted) fabrics are selected and reacted with sodium hydroxide, morpholine, and cellulase enzyme. The fabrics are then dyed by some selected dyes such as annatto, onion, pomegranate, indigo, myrobalan, bar berry (natural dyes); and reactive and sulphur dyes (synthetic) respectively and subsequently finished. These fabrics are then analyzed for mechanical and surface properties from KES-F, and assessed by SEM and FTIR.
\end{abstract}

Keywords: Cotton fabrics; Chemical treatment; KES-F; SEM; FTIR

\section{Introduction}

Today cotton is the most used textile fiber in the world [1]. World textile fiber consumption in the end of $20^{\text {th }}$ century was approximately 45 million tons. Of this total, cotton represented approximately 20 million tons [2]. India holds the largest area of $8 \mathrm{~m}$ ha under cotton cultivation and ranked third in world's cotton production, next to China \& USA and second largest consumer of cotton $[2,3]$.

Unlike synthetic fibers, cotton is a natural product [4] and nonallergic since it doesn't irritate sensitive skin or cause allergies. Cotton has a high absorbency [5] rate and holds up to 27 times its own weight in water. Cotton swells in a high humidity environment, in water and in concentrated solutions of certain acids, salts and bases [6]. Chemical treatment of cotton cellulose to alter physical properties of the fibers without changing their fibrous form is a common practice in the textile industry [7].

In the application of dyestuffs to cotton, several factors are considered as of prime importance [8-10]. The importance of natural dyes has increased presently, with increased awareness about harmful effects of chemical dyes both in production and in its usage by human beings [11-13]. This dye has the rare distinction of being a dye whose use can be traced back to antiquity and which continues to be as commonly used all over the world today as it is in the ancient times [14-17].

This research work focuses on the treatment of cotton (woven and knitted) fabrics with sodium hydroxide, morpholine, and cellulase enzyme in order to improve its behavior revealed by dyeing and finishing. The cotton fabrics (treated and untreated) were dyed by some selected dyes such as annatto, onion, pomegranate, indigo, myrobalan, bar berry (natural dyes); and reactive and sulphur dyes (synthetic) respectively and subsequently finished. These fabrics were then assessed for mechanical and surface properties from KES-F, SEM analysis and FTIR studies.

\section{Experimental}

\section{Materials}

Cotton (woven and knitted) fabrics with following specifications were used in this study (Table 1). Natural dyes annatto (Bixa orellana), onion (Allium cepa), pomegranate (Punicagranatum), indigo (Indigofera tinctoria), myrobalan (Terminalia chebula), bar berry (Berberis vulgaris) and synthetic dyes reactive dye (reactive red HB-C.I. No. Red 24), and sulphur dye (sulphur black-C.I. No. sulphur Black 1) used were in the commercial grade. The commercial Super FX UltraSoft 2015 (Tirupur, India) was used for finishing on cotton fabrics. The other chemicals mentioned elsewhere for this study were in AR grade.

\section{Methods}

Pretreatment on cotton (woven and knitted) fabrics: The cotton fabrics (woven and knitted) were pretreated (scouring and bleaching) as per the established technique [18].

Sodium hydroxide treatment on cotton (woven and knitted) fabrics: The cotton fabrics (woven and knitted) were treated with sodium hydroxide of the concentration $15 \%$ (owm) for one hour at $85^{\circ} \mathrm{C}$.

Morpholine treatment on cotton (woven and knitted) fabrics: The cotton fabrics (woven and knitted) were treated with aqueous solution of morpholine $40 \%$ for one hour at $40^{\circ} \mathrm{C}$.

Cellulase enzyme treatment on cotton (woven and knitted) fabrics: The cotton fabrics (woven and knitted) were treated with Cellulase enzyme of the concentration $4.0 \%$ (owm) for one hour at $70^{\circ} \mathrm{C}$.

Dyeing of cotton (woven and knitted) fabrics: The dyeability of cotton fabrics (woven and knitted) was investigated using natural dyes

\begin{tabular}{|c|c|c|c|c|c|c|c|}
\hline \multicolumn{4}{|c|}{ Woven Fabric } & \multicolumn{3}{c|}{ Knitted fabric } \\
\hline $\begin{array}{c}\text { Ends/ } \\
\text { Inch }\end{array}$ & $\begin{array}{c}\text { Picks/ } \\
\text { Inch }\end{array}$ & GSM & \multicolumn{2}{|c|}{ Yarn Count (Ne) } & $\begin{array}{c}\text { Yarn } \\
\text { count } \\
\text { (Ne) }\end{array}$ & GSM & $\begin{array}{c}\text { Loop } \\
\text { length } \\
\text { (mm) }\end{array}$ \\
\hline 84 & 94 & 146.1 & 27.1 & 26.1 & 27.5 & 136.9 & 2.6 \\
\hline
\end{tabular}

Table 1: Cotton (woven and knitted) fabrics with following specifications.

*Corresponding author: Moses JJ, Department of Applied Science, PSG College of Technology, Coimbatore 641 004, India, Tel: 0422-257-2177; E-mail: jj_moses2k2@yahoo.co.in

Received April 09, 2014; Accepted May 02, 2014; Published May 05, 2014

Citation: Moses JJ, Venkataraman VK (2014) Study of Mechanical and Surface Properties on some Chemical Treated Cotton Fabric by KES-F, SEM and FTIR Analysis. J Textile Sci Eng S2: 004. doi:10.4172/2165-8064.S2-004

Copyright: (C) 2014 Moses JJ, et al. This is an open-access article distributed under the terms of the Creative Commons Attribution License, which permits unrestricted use, distribution, and reproduction in any medium, provided the original author and source are credited. 
[annatto (Bixa orellana), onion (Allium cepa), pomegranate (Punica granatum), indigo (Indigofera tinctoria), myrobalan (Terminalia chebula), and bar berry (Berberis vulgaris)] and synthetic dyes [reactive dye (reactive red HB) and sulphur dye (sulphur black)]. Dyeing was carried out at boil for two hours with a material to liquor ratio of 1:20 and at $\mathrm{pH}$ of around 10 (maintained by $\mathrm{Na}_{2} \mathrm{CO}_{3} / \mathrm{NaOH}$ ) as per the established technique of dyeing for natural and synthetic dyes [19,20].

Silicone softener finishing on cotton (woven and knitted) fabrics: The fabrics were finished with silicone softener (Super FX UltraSoft 2015) (Dosage: $5-10 \mathrm{gpl}, \mathrm{pH}: 5-7,30^{\circ} \mathrm{C}, 70-80 \%$ pick up, padded and dried at room temperature) and tested accordingly $[21,22]$.

Objective assessment on dyed and finished cotton (woven and knitted) fabrics by KES-F: The mechanical and surface properties of the dyed and finished woven and knitted cotton fabrics were assessed by Kawabata evaluation system (KES-F) [23].

SEM Study on dyed and finished cotton (woven and knitted) fabrics: Scanning electron microscope studies were carried out on dyed and finished woven and knitted cotton fabrics from $30 \mathrm{kV}$ scanning electron microscope JEOL (Japan) Model JSM-6360 [24].

FTIR analysis for dyed and finished cotton (woven and knitted) fabrics: Fourier Transfer Infra-Red (FTIR) spectrophotometer (Shimadzu, Japan) was used to analyze the functional groups. The

\begin{tabular}{|c|c|c|c|c|c|c|c|c|c|c|}
\hline \multirow[t]{4}{*}{ S.No. } & \multirow[t]{3}{*}{ Dyes } & \multicolumn{9}{|c|}{ PHV of woven cotton fabric } \\
\hline & & \multirow[t]{2}{*}{ UT } & \multicolumn{2}{|c|}{1} & \multicolumn{2}{|c|}{2} & \multicolumn{2}{|c|}{3} & \multicolumn{2}{|c|}{4} \\
\hline & & & F1 & F2 & F1 & F2 & F1 & F2 & F1 & F2 \\
\hline & Smoothness: & & & & & & & & & \\
\hline 1 & Undyed & 2.7 & 5.0 & 5.4 & 7.3 & 7.8 & 6.6 & 6.7 & 6.4 & 6.5 \\
\hline 2 & Annatto & 2.9 & 5.4 & 5.8 & 7.5 & 7.9 & 6.7 & 6.8 & 6.5 & 6.6 \\
\hline 3 & Onion & 2.8 & 5.3 & 5.5 & 7.4 & 7.6 & 6.6 & 6.7 & 6.5 & 6.6 \\
\hline 4 & Pomogranate & 2.8 & 5.3 & 5.5 & 7.6 & 7.7 & 6.8 & 7.0 & 6.6 & 6.7 \\
\hline 5 & Indigo & 2.7 & 5.2 & 5.5 & 7.4 & 7.6 & 6.7 & 6.8 & 6.5 & 6.7 \\
\hline 6 & Myrobalan & 2.8 & 5.2 & 5.5 & 7.6 & 7.7 & 6.8 & 6.9 & 6.5 & 6.6 \\
\hline 7 & Bar berry & 2.8 & 5.3 & 5.6 & 7.7 & 7.9 & 6.9 & 7.1 & 6.7 & 6.8 \\
\hline 8 & Reactive Dye & 3.2 & 5.7 & 6.0 & 7.7 & 7.8 & 6.8 & 7.0 & 6.6 & 6.7 \\
\hline \multirow[t]{2}{*}{9} & Sulphur Dye & 2.3 & 4.9 & 5.3 & 7.5 & 7.6 & 6.6 & 6.8 & 6.4 & 6.5 \\
\hline & Stiffness: & & & & & & & & & \\
\hline 1 & Undyed & 5.0 & 4.9 & 4.6 & 4.6 & 4.3 & 4.7 & 4.4 & 4.8 & 4.5 \\
\hline 2 & Annatto & 4.8 & 4.8 & 4.5 & 4.5 & 4.2 & 4.6 & 4.3 & 4.7 & 4.4 \\
\hline 3 & Onion & 4.7 & 4.8 & 4.5 & 4.5 & 4.2 & 4.6 & 4.3 & 4.7 & 4.4 \\
\hline 4 & Pomogranate & 4.8 & 4.8 & 4.5 & 4.5 & 4.2 & 4.6 & 4.3 & 4.7 & 4.4 \\
\hline 5 & Indigo & 4.8 & 4.9 & 4.6 & 4.6 & 4.4 & 4.7 & 4.5 & 4.8 & 4.5 \\
\hline 6 & Myrobalan & 4.5 & 4.8 & 4.5 & 4.5 & 4.2 & 4.6 & 4.3 & 4.7 & 4.4 \\
\hline 7 & Bar berry & 4.8 & 4.8 & 4.5 & 4.5 & 4.2 & 4.6 & 4.3 & 4.7 & 4.4 \\
\hline 8 & Reactive Dye & 4.7 & 4.6 & 4.2 & 4.3 & 3.9 & 4.4 & 4.0 & 4.5 & 4.1 \\
\hline \multirow[t]{2}{*}{9} & Sulphur Dye & 4.9 & 4.9 & 4.6 & 4.6 & 43 & 4.7 & 4.4 & 4.8 & 4.5 \\
\hline & Fullness: & & & & & & & & & \\
\hline 1 & Undyed & 4.8 & 7.7 & 8.2 & 9.4 & 9.7 & 8.3 & 8.5 & 8.1 & 8.4 \\
\hline 2 & Annatto & 4.9 & 8.3 & 8.7 & 9.9 & 10.7 & 9.2 & 9.5 & 9.0 & 9.4 \\
\hline 3 & Onion & 4.9 & 8.3 & 8.5 & 9.6 & 10.6 & 9.1 & 9.4 & 8.9 & 9.3 \\
\hline 4 & Pomogranate & 4.8 & 8.1 & 8.5 & 9.5 & 10.4 & 9.0 & 9.4 & 8.8 & 9.3 \\
\hline 5 & Indigo & 4.8 & 8.2 & 8.5 & 9.5 & 10.5 & 9.0 & 9.3 & 8.8 & 9.2 \\
\hline 6 & Myrobalan & 4.8 & 8.3 & 8.4 & 9.4 & 10.4 & 9.0 & 9.4 & 8.8 & 9.3 \\
\hline 7 & Bar berry & 4.9 & 8.3 & 8.6 & 9.5 & 10.5 & 9.1 & 9.4 & 8.9 & 9.3 \\
\hline 8 & Reactive Dye & 5.0 & 8.5 & 8.8 & 9.9 & 10.8 & 9.2 & 9.5 & 9.0 & 9.4 \\
\hline 9 & Sulphur Dye & 4.8 & 8.2 & 8.5 & 9.6 & 10.4 & 9.0 & 9.4 & 8.8 & 9.3 \\
\hline
\end{tabular}

UT $\rightarrow$ undyed/unfinished/untreated cotton 1 . Untreated cotton 2 . Sodium hydroxide treated cotton 3. Morpholine treated cotton 4. Cellulase enzyme treated cotton.

Table 1a: Primary hand value (PHV) of dyed and finished woven cotton fabric.

\begin{tabular}{|c|c|c|c|c|c|c|c|c|c|c|}
\hline \multirow[t]{4}{*}{ S.No. } & \multirow[t]{3}{*}{ Dyed Samples } & \multicolumn{9}{|c|}{ PHV of knitted cotton fabric } \\
\hline & & \multirow[t]{2}{*}{ UT } & \multicolumn{2}{|c|}{1} & \multicolumn{2}{|c|}{2} & \multicolumn{2}{|c|}{3} & \multicolumn{2}{|c|}{4} \\
\hline & & & F1 & F2 & F1 & F2 & F1 & F2 & F1 & $\mathbf{F 2}$ \\
\hline & Smoothness: & & & & & & & & & \\
\hline 1 & Undyed & 2.4 & 4.8 & 5.2 & 6.8 & 7.1 & 6.2 & 6.3 & 5.9 & 6.2 \\
\hline 2 & Annatto & 2.8 & 5.2 & 5.6 & 7.1 & 7.3 & 6.6 & 6.7 & 6.2 & 6.4 \\
\hline 3 & Onion & 2.7 & 5.1 & 5.4 & 6.9 & 7.2 & 6.5 & 6.7 & 6.2 & 6.5 \\
\hline 4 & Pomogranate & 2.6 & 4.9 & 5.3 & 6.7 & 7.2 & 6.3 & 6.6 & 6.0 & 6.3 \\
\hline 5 & Indigo & 2.7 & 5.0 & 5.4 & 6.6 & 7.3 & 6.4 & 6.6 & 6.1 & 6.4 \\
\hline 6 & Myrobalan & 2.6 & 4.9 & 5.3 & 6.6 & 7.3 & 6.3 & 6.5 & 6.0 & 6.3 \\
\hline 7 & Bar berry & 2.8 & 5.1 & 5.5 & 6.7 & 7.4 & 6.4 & 6.5 & 6.2 & 6.4 \\
\hline 8 & Reactive Dye & 3.1 & 5.5 & 5.9 & 7.0 & 7.5 & 6.6 & 6.7 & 6.4 & 6.6 \\
\hline \multirow[t]{2}{*}{9} & Sulphur Dye & 2.5 & 4.8 & 5.3 & 6.9 & 7.2 & 6.3 & 6.4 & 5.9 & 6.3 \\
\hline & Stiffness: & & & & & & & & & \\
\hline 1 & Undyed & 4.8 & 4.7 & 4.5 & 4.4 & 4.2 & 4.5 & 4.3 & 4.6 & 4.4 \\
\hline 2 & Annatto & 4.7 & 4.6 & 4.4 & 4.3 & 4.1 & 4.4 & 4.2 & 4.5 & 4.3 \\
\hline 3 & Onion & 4.6 & 4.7 & 4.4 & 4.4 & 4.2 & 4.5 & 4.3 & 4.6 & 4.3 \\
\hline 4 & Pomogranate & 4.7 & 4.8 & 4.4 & 4.5 & 4.1 & 4.6 & 4.2 & 4.7 & 4.3 \\
\hline 5 & Indigo & 4.7 & 4.8 & 4.5 & 4.5 & 4.2 & 4.6 & 4.3 & 4.7 & 4.4 \\
\hline 6 & Myrobalan & 4.6 & 4.7 & 4.5 & 4.4 & 4.2 & 4.5 & 4.3 & 4.6 & 4.4 \\
\hline 7 & Bar berry & 4.6 & 4.7 & 4.4 & 4.4 & 4.1 & 4.5 & 4.2 & 4.6 & 4.3 \\
\hline 8 & Reactive Dye & 4.6 & 4.5 & 4.1 & 4.2 & 3.8 & 4.3 & 3.9 & 4.4 & 4.0 \\
\hline \multirow[t]{2}{*}{9} & Sulphur Dye & 4.8 & 4.8 & 4.5 & 4.5 & 4.2 & 4.6 & 4.3 & 4.7 & 4.4 \\
\hline & Fullness: & & & & & & & & & \\
\hline 1 & Undyed & 4.6 & 7.4 & 7.9 & 8.4 & 8.7 & 7.9 & 8.3 & 7.7 & 8.1 \\
\hline 2 & Annatto & 4.7 & 8.1 & 8.6 & 8.9 & 9.4 & 8.7 & 9.0 & 8.4 & 8.8 \\
\hline 3 & Onion & 4.9 & 8.1 & 8.5 & 8.8 & 9.3 & 8.6 & 9.0 & 8.4 & 8.7 \\
\hline 4 & Pomogranate & 4.8 & 8.1 & 8.4 & 8.9 & 9.3 & 8.7 & 8.9 & 8.4 & 8.6 \\
\hline 5 & Indigo & 4.8 & 8.0 & 8.4 & 8.8 & 9.2 & 8.6 & 8.8 & 8.3 & 8.6 \\
\hline 6 & Myrobalan & 4.9 & 8.0 & 8.5 & 8.9 & 9.3 & 8.6 & 8.9 & 8.3 & 8.7 \\
\hline 7 & Bar berry & 4.8 & 8.1 & 8.5 & 8.9 & 9.4 & 8.7 & 8.9 & 8.4 & 8.7 \\
\hline 8 & Reactive Dye & 4.9 & 8.4 & 8.7 & 9.0 & 9.5 & 8.9 & 9.0 & 8.7 & 8.8 \\
\hline 9 & Sulphur Dye & 4.7 & 8.1 & 8.4 & 8.9 & 9.2 & 8.6 & 8.8 & 8.4 & 8.6 \\
\hline
\end{tabular}

UT $\rightarrow$ undyed/unfinished/untreated cotton 1 . Untreated cotton 2 . Sodium hydroxide treated cotton 3. Morpholine treated cotton 4. Cellulase enzyme treated cotton.

Table 1b: Primary hand value (PHV) of dyed and finished knitted cotton fabric.

data reveal about the color absorption properties of the organic dye molecules with respect to the functional groups, aromatic and achromatic ring chains and indicated the presence of structural groups in the dye molecules [25].

\section{Results and Discussion}

\section{Mechanical and surface properties from KES-F}

The mechanical and surface properties of the dyed and finished cotton fabrics (woven \& knitted) were objectively assessed by KES-F The Primary Hand Value (PHV) (of both woven and knitted fabrics), bending length (of only woven fabric) fabrics, and crease recovery (of only woven fabric) of the dyed and finished cotton fabrics were carried out by this system and data are presented in Tables 1a,1b, 2, 3 respectively.

Primary hand value (PHV) of dyed and finished cotton (woven and knitted) fabrics: The parameters evaluated from KES-F of dyed and finished cotton fabrics for the primary hand value of woven and knitted fabrics are given in Table 1a and $1 \mathrm{~b}$ respectively. From these Table $1 \mathrm{a}, 1 \mathrm{~b}$ it is seen that the smoothness is observed more on the dyed and finished sodium hydroxide treated [2] cotton fabric (190\% to $200 \%)$ followed by morpholine treated [3] (150\% to $160 \%)$, enzyme treated [4] (130\% to $140 \%)$ and untreated [1] (90\% to $100 \%)$ cotton 


\begin{tabular}{|c|c|c|c|c|c|c|c|c|c|c|}
\hline \multirow[t]{3}{*}{ S.No. } & \multirow[t]{3}{*}{ Dyes } & \multicolumn{9}{|c|}{ Bending length $(\mathrm{mm})$ of woven cotton fabric Warp $(\mathrm{Cw})$} \\
\hline & & \multirow[t]{2}{*}{ UT } & \multicolumn{2}{|c|}{1} & \multicolumn{2}{|c|}{2} & \multicolumn{2}{|c|}{3} & \\
\hline & & & F1 & F2 & F1 & F2 & F1 & F2 & F1 & F2 \\
\hline 1 & Undyed & 10.8 & 9.6 & 9.4 & 9 & 8.8 & 9.2 & 9 & 9.4 & 9.2 \\
\hline 2 & Annatto & 10.3 & 9.5 & 9.3 & 8.9 & 8.6 & 9.1 & 8.8 & 9.3 & 9 \\
\hline 3 & Onion & 10.4 & 9.4 & 9.3 & 8.8 & 8.7 & 9 & 8.9 & 9.2 & 9.1 \\
\hline 4 & Pomogranate & 10.3 & 9.5 & 9.2 & 8.9 & 8.6 & 9.1 & 8.8 & 9.3 & 9 \\
\hline 5 & Indigo & 10.4 & 9.5 & 9.3 & 8.9 & 8.7 & 9.1 & 8.9 & 9.3 & 9.1 \\
\hline 6 & Myrobalan & 10.4 & 9.4 & 9.3 & 8.8 & 8.7 & 9 & 8.9 & 9.2 & 9.1 \\
\hline 7 & Bar berry & 10.3 & 9.4 & 9.4 & 8.8 & 8.7 & 9 & 8.9 & 9.2 & 9.1 \\
\hline 8 & Reactive Dye & 10.4 & 9.3 & 9.2 & 8.7 & 8.6 & 8.9 & 8.8 & 9.1 & 9 \\
\hline \multirow[t]{4}{*}{9} & Sulphur Dye & 10.4 & 9.2 & 9.3 & 8.6 & 8.5 & 8.8 & 8.7 & 9 & 8.9 \\
\hline & & \multicolumn{9}{|c|}{ Bending length $(\mathrm{mm})$ of woven cotton fabric Warp (Cf) } \\
\hline & & & & \multicolumn{2}{|c|}{2} & \multicolumn{2}{|c|}{3} & \\
\hline & & UT & F1 & F2 & F1 & F2 & F1 & F2 & F1 & F2 \\
\hline 1 & Undyed & 10.6 & 9.4 & 9.2 & 8.8 & 8.6 & 9 & 8.8 & 9.2 & 9 \\
\hline 2 & Annatto & 10.2 & 9.3 & 9.1 & 8.7 & 8.5 & 8.9 & 8.7 & 9.1 & 8.9 \\
\hline 3 & Onion & 10.2 & 9.2 & 9.1 & 8.6 & 8.5 & 8.8 & 8.7 & 9 & 8.9 \\
\hline 4 & Pomogranate & 10.2 & 9.3 & 9.1 & 8.7 & 8.5 & 8.9 & 8.7 & 9.1 & 8.9 \\
\hline 5 & Indigo & 10.2 & 9.3 & 9.2 & 8.7 & 8.6 & 8.9 & 8.8 & 9.1 & 9 \\
\hline 6 & Myrobalan & 10.2 & 9.3 & 9.1 & 8.7 & 8.5 & 8.9 & 8.7 & 9.1 & 8.9 \\
\hline 7 & Bar berry & 10.1 & 9.2 & 9.1 & 8.6 & 8.5 & 8.8 & 8.7 & 9 & 8.9 \\
\hline 8 & Reactive Dye & 10.1 & 9.1 & 9 & 8.5 & 8.3 & 8.7 & 8.6 & 8.9 & 8.8 \\
\hline 9 & Sulphur Dye & 10.3 & 9.1 & 9.2 & 8.5 & 8.4 & 8.7 & 8.7 & 8.9 & 9 \\
\hline
\end{tabular}

UT $\rightarrow$ undyed/unfinished/untreated cotton 1) Untreated cotton. 2) Sodium hydroxide treated cotton. 3) Morpholine treated cotton. 4) Cellulase enzyme treated cotton.

Table 2: Bending length of dyed and finished woven cotton fabric.

\begin{tabular}{|c|c|c|c|c|c|c|c|c|c|c|}
\hline \multirow[t]{3}{*}{ S.No. } & \multirow[t]{3}{*}{ Dyes } & \multicolumn{9}{|c|}{ Crease recovery $\left(^{\circ}\right)$ of woven cotton fabric Warp $(\mathrm{Cw})$} \\
\hline & & \multirow[t]{2}{*}{ UT } & \multicolumn{2}{|c|}{1} & \multicolumn{2}{|c|}{2} & \multicolumn{2}{|c|}{3} & \multicolumn{2}{|c|}{4} \\
\hline & & & F1 & F2 & F1 & F2 & F1 & F2 & F1 & $\mathbf{F 2}$ \\
\hline 1 & Undyed & 112 & 109 & 107 & 99 & 96 & 104 & 100 & 107 & 104 \\
\hline 2 & Annatto & 109 & 103 & 99 & 94 & 89 & 98 & 93 & 101 & 96 \\
\hline 3 & Onion & 109 & 105 & 99 & 95 & 90 & 99 & 94 & 103 & 97 \\
\hline 4 & Pomogranate & 110 & 106 & 100 & 96 & 89 & 101 & 94 & 104 & 97 \\
\hline 5 & Indigo & 110 & 106 & 100 & 97 & 91 & 101 & 95 & 104 & 98 \\
\hline 6 & Myrobalan & 110 & 105 & 100 & 95 & 91 & 99 & 95 & 103 & 98 \\
\hline 7 & Bar berry & 109 & 104 & 98 & 94 & 88 & 98 & 92 & 101 & 95 \\
\hline 8 & Reactive Dye & 104 & 100 & 96 & 91 & 87 & 94 & 91 & 97 & 94 \\
\hline \multirow[t]{4}{*}{9} & Sulphur Dye & 111 & 107 & 102 & 96 & 92 & 100 & 96 & 104 & 99 \\
\hline & & \multicolumn{9}{|c|}{ Crease recovery $\left(^{\circ}\right)$ of woven cotton fabric Warp (Cf) } \\
\hline & & & \multicolumn{2}{|c|}{1} & \multicolumn{2}{|c|}{2} & \multicolumn{2}{|c|}{3} & \multicolumn{2}{|c|}{4} \\
\hline & & UT & F1 & F2 & F1 & F2 & F1 & F2 & F1 & F2 \\
\hline 1 & Undyed & 114 & 112 & 110 & 105 & 103 & 108 & 106 & 110 & 108 \\
\hline 2 & Annatto & 111 & 104 & 102 & 97 & 95 & 100 & 98 & 102 & 100 \\
\hline 3 & Onion & 111 & 107 & 104 & 100 & 97 & 103 & 100 & 105 & 102 \\
\hline 4 & Pomogranate & 111 & 108 & 103 & 101 & 96 & 104 & 99 & 106 & 101 \\
\hline 5 & Indigo & 112 & 108 & 104 & 102 & 97 & 104 & 100 & 106 & 102 \\
\hline 6 & Myrobalan & 112 & 108 & 103 & 101 & 96 & 104 & 99 & 106 & 101 \\
\hline 7 & Bar berry & 111 & 106 & 103 & 99 & 96 & 102 & 99 & 104 & 101 \\
\hline 8 & Reactive Dye & 105 & 104 & 100 & 97 & 94 & 100 & 96 & 102 & 98 \\
\hline 9 & Sulphur Dye & 113 & 109 & 105 & 100 & 97 & 104 & 100 & 107 & 103 \\
\hline
\end{tabular}

UT $\rightarrow$ undyed/unfinished/untreated cotton 1) Untreated cotton. 2) Sodium hydroxide treated cotton. 3) Morpholine treated cotton. 4) Cellulase enzyme treated cotton.

Table 3: Crease recovery $\left(^{\circ}\right)$ of dyed and finished woven cotton fabric.

fabrics respectively. The undyed/unfinished untreated [UT] cotton fabrics show very low smoothness values compared to the above mentioned treated fabrics. The dyed fabrics $[\mathrm{F} 1 / 1,2,3,4]$ when finished [F2] with the finishing agent-Super FX UltraSoft 2015, the smoothness is considerably increased $(2.5 \%$ to $5 \%)$ in all these cases [1-4]. The increased smoothness values on the dyed and finished cotton fabrics $[\mathrm{F} 1, \mathrm{~F} 2 / 1,2,3,4]$ compared to the untreated unfinished cotton fabrics [UT] are due to the good application of dyeing and finishing as promoted by good treatments [2-4]. Among the dyes, the differences in smoothness values on the cotton fabrics [UT, F1, F2/1,2,3,4] are only marginal. The stiffness of the fabrics is reduced due to the sodium hydroxide treatment, morphology treatment and enzyme treatment followed by dyeing and finishing. Compared to all treated [F1, F2/2,3,4] and untreated [UT, and F1, F2/1] fabrics the sodium hydroxide treated cotton fabrics show reduced stiffness, this is due to the good flexibility generated by sodium hydroxide; followed by morpholine treatment, enzyme treatment and untreated dyed and finished cotton fabrics $(10 \%$ to $15 \%$ in general in all these cases). The fullness is maximum $(80 \%$ to $200 \%$ ) on the sodium hydroxide treated cotton fabrics followed by morpholine treated, enzyme treated and untreated fabrics. In general, the primary hand value is maximum for the sodium hydroxide treated [2] fabrics followed by morpholine treated [3], enzyme treated [4] and untreated [UT, 1] dyed [F1] and finished [F2] woven and knitted cotton fabrics (Table 1a and 1b).

\section{Bending length of dyed and finished woven cotton fabric}

The values of the bending length of untreated [UT, 1] and treated [sodium hydroxide, morpholine and enzyme] dyed and finished woven cotton fabrics are given in Table 2. From this table it is given as the data of the bending length both in warp and weft directions respectively of cotton fabric treated with sodium hydroxide, morpholine and enzyme followed by dyeing and finishing. It is evident from the Table 2 that bending length both in warp and weft directions of dyed [F1] and finished [F2] cotton fabric treated with sodium hydroxide [2] is least followed by morpholine treated [3], enzyme treated [4] and untreated [1] cotton fabrics (5\% to $15 \%$ ) respectively. The undyed/unfinished

\begin{tabular}{|c|c|c|}
\hline S.No. & Peak range $\left(\mathrm{cm}^{-1}\right)$ & Functional groups \\
\hline 1 & $3600-3700$ & Non bonded hydroxyl group-OH- \\
\hline 2 & $3300-3400$ & Alkyne-C-H- stretch \\
\hline 3 & $3200-3300$ & Hydroxyl group ( $\mathrm{H}$-bonded-OH- stretch ) \\
\hline 4 & $3000-3200$ & Aromatic ring (-C-H- stretch) \\
\hline 5 & $2900-3000$ & Methylene- $\mathrm{CH}$ - stretch \\
\hline 6 & $2700-2800$ & Terminal aldehyde- $\mathrm{CH}$ - stretch \\
\hline 7 & $2600-2700$ & Hydrogen bonded-OH-group \\
\hline 8 & $2500-2600$ & Thiols (-S-H- stretch) \\
\hline 9 & $2400-2500$ & $-\mathrm{CH}$ - stretch of aromatic compounds \\
\hline 10 & $2300-2400$ & -OH-stretching of Carboxylic acid \\
\hline 11 & $2200-2300$ & Cyano compounds, disubstituted alkynes \\
\hline 12 & $2100-2200$ & C-triple bond-C- stretch \\
\hline 13 & $2000-2100$ & Cyanide ion and related ion \\
\hline 14 & $1800-2000$ & Transition metal carbonyl group \\
\hline 15 & $1700-1800$ & Carbonyl group \\
\hline 16 & $1600-1700$ & -C-double bond-C stretch \\
\hline 17 & $1500-1600$ & Aromatic ring stretch-NH-bend \\
\hline 18 & $1400-1500$ & Organic Sulphates \\
\hline 19 & $1300-1400$ & $-\mathrm{OH}$ - bend \\
\hline 20 & $1200-1300$ & Aromatic primary amine $-\mathrm{CN}$ - stretch \\
\hline 21 & $1100-1200$ & Secondary amine $-\mathrm{CN}$ - stretch \\
\hline 22 & $1000-1100$ & -C-C- stretch \\
\hline 23 & $900-1000$ & Cyclo hexane ring vibrations \\
\hline 24 & $800-900$ & Peroxides -C-O-O-stretch \\
\hline 25 & $700-800$ & Skeletal -C-C- vibrations \\
\hline 26 & $600-700$ & Aliphatic Bromo compounds \\
\hline 27 & $500-600$ & -C-I- stretch \\
\hline
\end{tabular}

Table 4: FTIR analysis of dyed woven cotton fabric. 
Citation: Moses JJ, Venkataraman VK (2014) Study of Mechanical and Surface Properties on some Chemical Treated Cotton Fabric by KES-F, SEM and FTIR Analysis. J Textile Sci Eng S2: 004. doi:10.4172/2165-8064.S2-004

untreated [UT] cotton fabric shows the maximum bending length (warp and weft) which is periodically reduced after the treatments such as enzyme, morpholine and sodium hydroxide and subsequent dyeing and finishing. These treatments reduce the bending lengths on the cotton fabrics and sodium hydroxide treatment tops the list in this reduction followed by morpholine and enzyme treatments. Dyeing and finishing also further enhances the reduction in bending lengths on all these fabrics. There are not many influences in the differences of bending length due to the change of dyes (Annatto, Onion, Pomogranate, Indigo, Myrobalan, Bar berry, Reactive Dye and Sulphur dye). The warp directions have marginally more bending length values in all these woven cotton fabrics.

\section{Crease recovery $\left(^{\circ}\right)$ of dyed and finished woven cotton fabric}

The data of the crease recovery both in warp and weft directions of dyed and finished woven cotton fabric treated with sodium hydroxide, morpholine and enzyme are given in Table 3 . From this table, it is clearly seen that the crease recovery both in warp and weft directions of dyed [F1] and finished [F2] cotton fabric treated with sodium hydroxide [2] is minimum compared to morpholine treated [3], enzyme treated

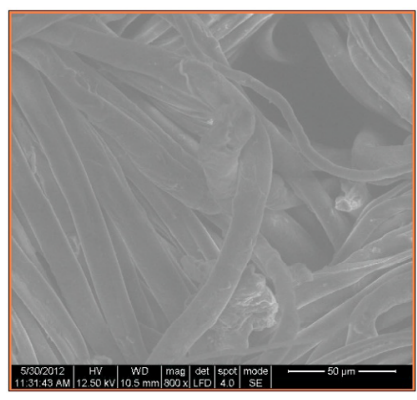

(1)

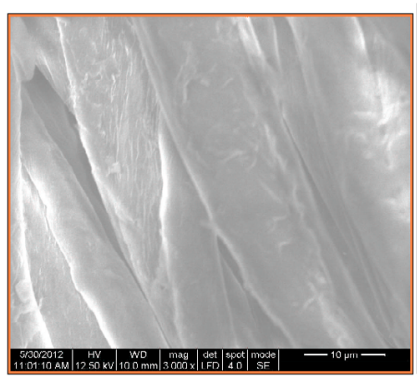

(1b)

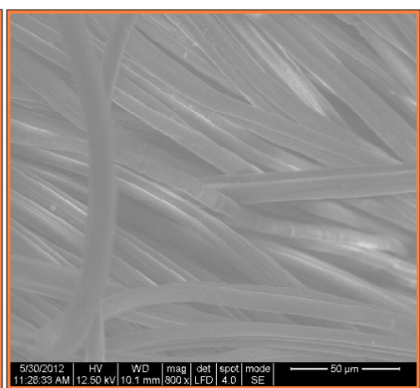

(1a)

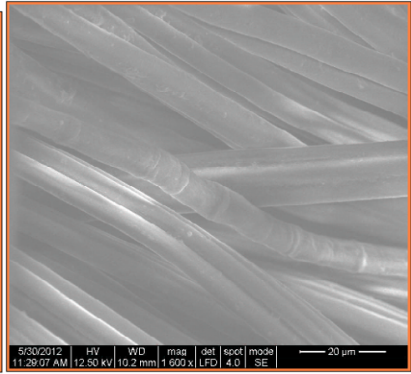

(1c)

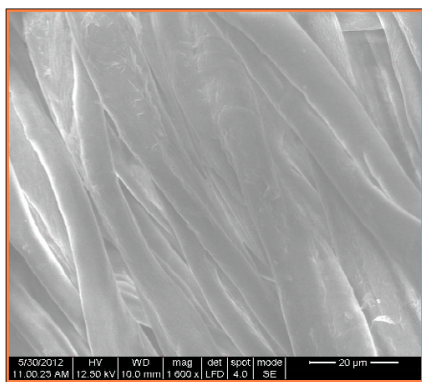

(1d)

Figure 1: SEM micrograph of undyed / unfinished untreated woven cotton fabric. 1a: SEM micrograph of untreated, dyed and finished woven cotton fabrics. 1b: SEM micrograph of sodium hydroxide treated, dyed and finished woven cotton fabrics. 1c: SEM micrograph of morpholine treated, dyed and finished woven cotton fabrics. 1d: SEM micrograph of enzyme treated, dyed and finished woven cotton fabrics.

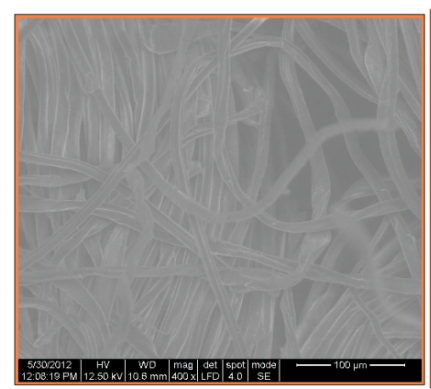

(2)

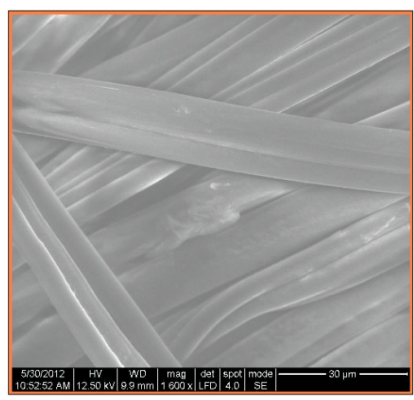

(2b)

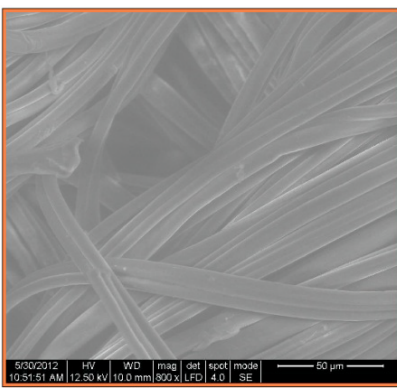

(2a)

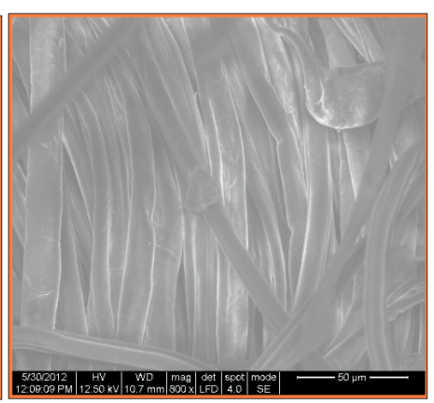

$(2 \mathrm{c})$

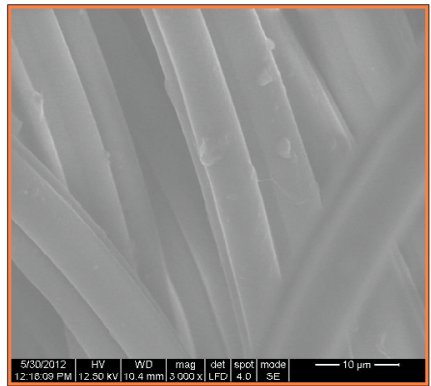

(2d)

Figure 2: SEM micrograph of undyed/unfinished untreated knitted cotton fabric. 2a: SEM micrograph of untreated, dyed and finished knitted cotton fabrics. $2 \mathrm{~b}$ : SEM micrograph of sodium hydroxide treated dyed finished woven cotton fabrics. 2c: SEM micrograph of morpholine treated, dyed and finished woven cotton fabrics. 2d: SEM micrograph of enzyme treated, dyed and finished knitted cotton fabrics.

[4] and untreated cotton fabrics [1] (5\% to 20\%) respectively. The undyed/unfinished untreated [UT] cotton fabric shows the maximum crease recovery (warp and weft) which is subsequently reduced after the treatments such as enzyme, morpholine and sodium hydroxide and subsequent dyeing and finishing. These treatments reduce the crease recovery on the cotton fabrics and sodium hydroxide treatment tops the list in this reduction followed by morpholine and enzyme treatments. Dyeing and finishing also further enhances the reduction in crease recovery on all these fabrics. The various dyes (Annatto, Onion, Pomogranate, Indigo, Myrobalan, Bar berry, Reactive Dye and Sulphur dye). do not give much influences in the differences of crease recovery. The weft directions have marginally more crease recovery values than those in warp directions in all these woven cotton fabrics.

\section{SEM analysis of cotton fabric}

The analysis of SEM images of dyed and/or finished cotton fabrics 

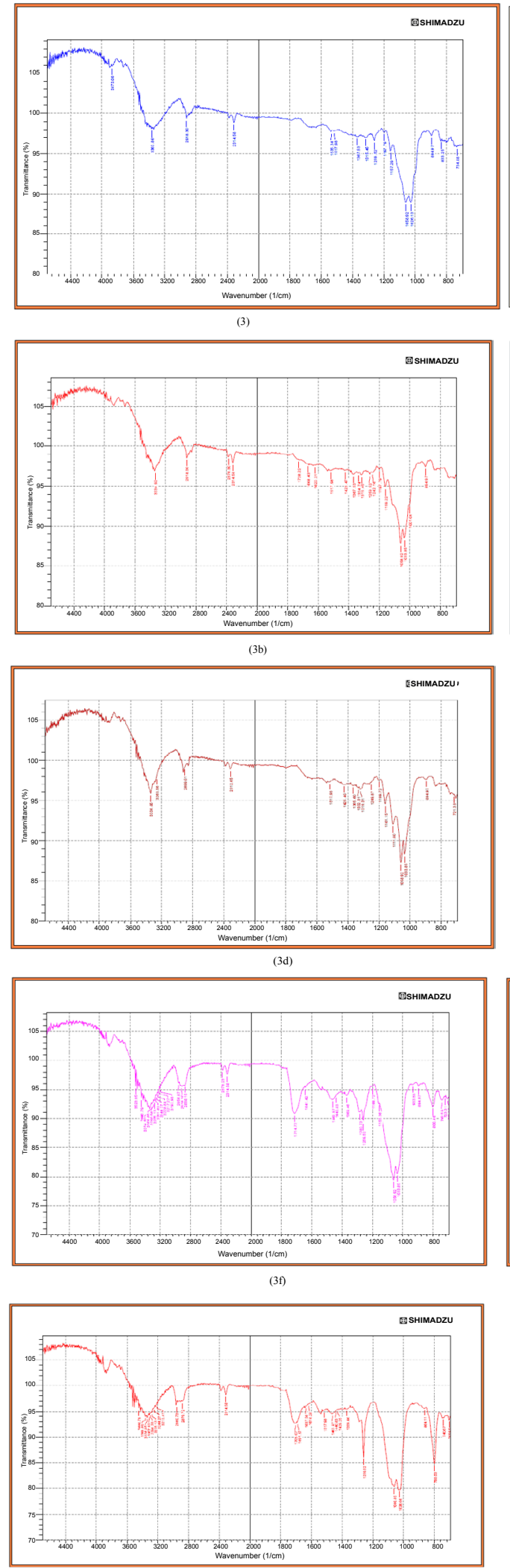
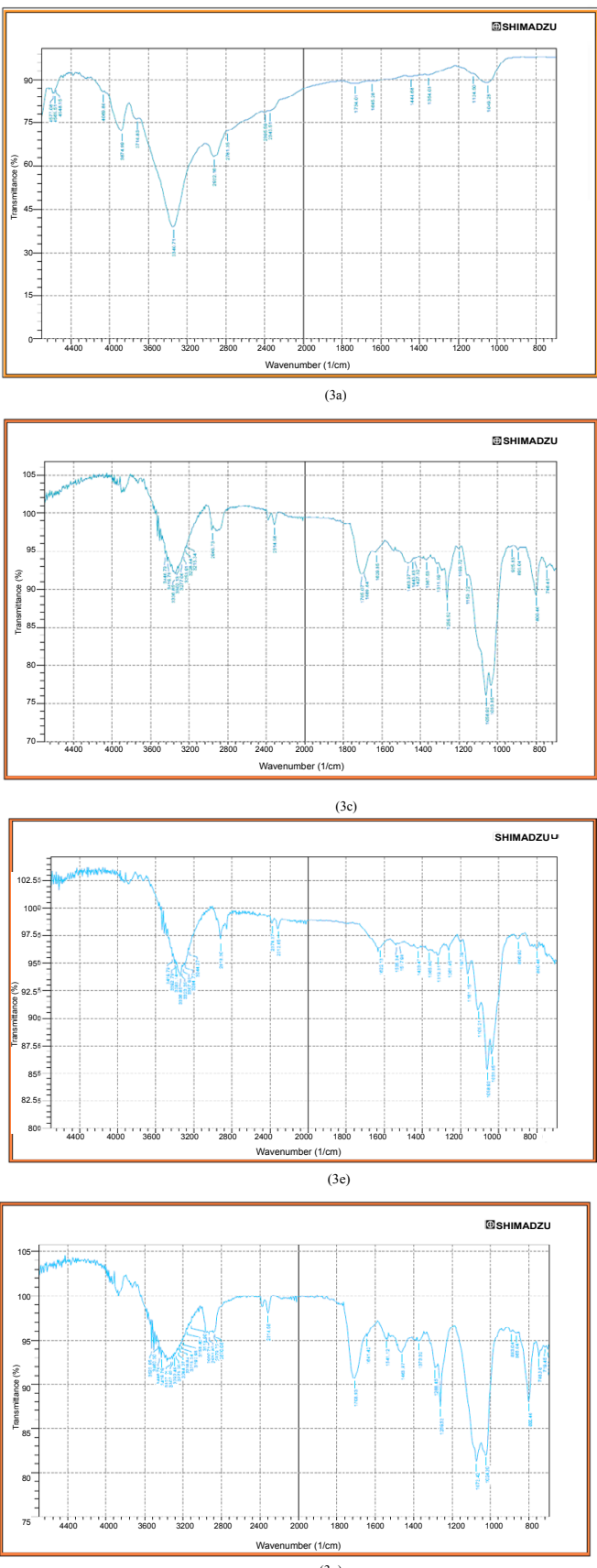

(3g)

Figure 3: FTIR spectra of barberry dye - yellow. 3a: FTIR spectra of untreated and dyed oven cotton fabrics. 3b: FTIR spectra of sodium hydroxide treated and dyed woven cotton fabrics. 3c: FTIR spectra of morpholine treated and dyed woven cotton fabrics. 3d: FTIR spectra of enzyme treated and dyed woven cotton fabrics. 3e: FTIR spectra of untreated, dyed and finished woven cotton fabrics. $3 f$ : FTIR spectra of sodium hydroxide treated, dyed and finished woven cotton fabrics. $3 \mathrm{~g}$ : FTIR spectra of morpholine treated, dyed and finished woven cotton fabrics. 3h: FTIR spectra of enzyme treated, dyed and finished woven cotton fabrics. 
(woven and knitted) have been discussed under this section. The dye was selected to dye some of the sample fabric based on the suitable performance. Accordingly, woven and knitted cotton fabrics were dyed with barberry dye. The fabrics were then finished and their respective SEM images were analyzed.

SEM analysis of woven cotton fabric: The SEM images of dyed and/or finished woven cotton fabrics (untreated, sodium hydroxide treated, morpholine treated and enzyme treated) are given in the Figure $1 \mathrm{a}, 1 \mathrm{~b}, 1 \mathrm{c}$, and $1 \mathrm{~d}$ respectively. Figure 1 is the SEM image of untreated (undyed and unfinished) woven cotton fabric. As the samples were treated with different chemicals and subsequently dyed and finished, it is evident from the (Figure 1a-1d) respectively that there are some clear differences in the respective images. Accordingly, Figure 1a shows the SEM image of untreated (dyed and finished) woven cotton fabric. Figure 1b-1d clearly gives the differences in the corresponding SEM images about the influences of the respective chemical treatments on woven cotton fabric. Hence, the dyed and finished sodium hydroxide treated cotton fabric (Figure 1b) gives good appearance in the SEM image followed by morpholine treated (Figure 1c) and enzyme treated (Figure 1d) respectively.

SEM analysis of knitted cotton fabric: The SEM images of dyed and/or finished knitted cotton fabrics (untreated, sodium hydroxide treated, morpholine treated and enzyme treated) are given in the Figure $2 \mathrm{a}-2 \mathrm{~d}$ respectively. Figure 2 is the SEM image of untreated (undyed and unfinished) knitted cotton fabric. As the samples were treated with different chemicals (sodium hydroxide, morpholine and enzyme) and subsequently dyed and finished, it is evident from the Figure 2a$2 \mathrm{~d}$ respectively, that there are some clear differences in the respective images. Accordingly, Figure 2a shows the SEM image of untreated (dyed and finished) knitted cotton fabric. Figure 2b, 2c, and $2 \mathrm{~d}$ clearly give the differences in the corresponding SEM images about the influences of the respective chemical treatments (sodium hydroxide, morpholine and enzyme) on knitted cotton fabrics. Hence, the dyed and finished sodium hydroxide treated cotton fabric (Figure $2 \mathrm{~b}$ ) gives good appearance in the SEM image followed by morpholine treated (Figure 2c) and enzyme treated (Figure 2d) respectively.

\section{FTIR analysis of dyed woven cotton fabric}

The cotton fabrics were dyed with different dyes. However as representation, barberry dye was selected for dyeing on woven cotton fabric only. The FTIR graph of barberry in the intact form is given in Figure 3. Subsequently the FTIR graph of the same dye after application on the woven cotton fabric (untreated, chemical treated and dyed) are given in the Figure 3a-3d respectively; and those for the finished fabrics (untreated, chemical treated, dyed and finished) are given in the Figure $3 \mathrm{e}-3 \mathrm{~h}$ respectively. The color generated for barberry dye is yellow when applied on the cotton fabric. The FTIR graphs for this barberry dye (intact and dyed and finished) are shown in Figures 3-3h respectively and are analyzed as per the following data (Table 4).

From these graphs it is evident that there are groups present in the barberry dye responsible for the reaction with the cotton textile fabric.

\section{Conclusion}

The conclusions drawn from the study are summarized below:

The primary hand value such as smoothness, stiffness and fullness is good in sodium hydroxide treated, morpholine treated and enzyme treated woven and knitted cotton fabrics respectively. Smoothness is observed more on the dyed and finished sodium hydroxide treated cotton fabric followed by morpholine treated; enzyme treated and untreated cotton fabrics respectively. The sodium hydroxide treated cotton fabrics have reduced stiffness due to the generation of good flexibility; followed by morpholine treatment, enzyme treatment and untreated dyed and finished cotton fabrics. The fullness is also maximum on the sodium hydroxide treated cotton fabrics followed by morpholine treated, enzyme treated and untreated fabrics. In general, the primary hand value is maximum for the sodium hydroxide treated fabrics followed by morpholine treated; enzyme treated and untreated dyed and finished woven and knitted cotton fabrics.

The bending length in both warp and weft directions of dyed and finished woven cotton fabric is good in sodium hydroxide treated one with least value followed by morpholine treated, enzyme treated and untreated fabrics respectively. The trend is common in both warp and weft directions; however the warp materials have an edge over the weft materials for the bending length.

The crease recovery in both warp and weft directions of dyed and finished woven cotton fabric treated with sodium hydroxide is minimum compared to morpholine treated, enzyme treated and untreated cotton fabric respectively revealed the good effect of sodium hydroxide. The trend is common in both warp and weft directions; however the weft materials have a little edge over the warp materials for the crease recovery.

SEM micrographs reveal that the dyed and finished sodium hydroxide treated cotton fabric gives good appearance followed by morpholine treated and enzyme treated respectively.

FTIR spectra prove that there are groups present in the barberry dye responsible for the reaction with the cotton textile fabric.

\section{Acknowledgements}

The authors wish to thank the Management and the Principal, PSG College of Technology, Coimbatore for given the permission and providing the necessary infrastructure. Thanks are also due to The Head, Department of Applied Science for the kind help in department laboratory supports.

\section{References}

1. Bouatay F, Meksi N, Slah F, Mohamed FM (2014) Chemical Modification of Cellulosic Fibers Using Eco-Friendly Compounds to Improve Dyeing with Cationic Dyes. J Text Sci Engg 4: 1-8

2. Lawrence Shaw H (1998) Cotton's Importance in the Textile Industry. [Symposium], Lima, Peru.

3. Simpson V (2011) India's Textile and apparel industry: Growth Potential and Trade and Investment Opportunities. US International Trade Commission, Washington DC, USA.

4. Duckett KE (1975) Surface Properties of Cotton Fibers, Surface Characteristics of Fibers and Textiles. Fiber Science Series, Marcel Dekker Inc, USA.

5. Meenaxi T, Archana S, Alka A (2009) Asian Dyer.

6. Brandrup J, Immergut EH, Grulke EA (1989) Polymer Handbook (4th edn.) John Wiley, New York, USA.

7. Lewin M (2007) Handbook of Fiber Chemistry, (3rd edn.). CRC Press, Baco Raton, USA

8. Morris CE, Vigo TL, Welch CM (1981) Binding of Organic Antimicrobial Agents to Cotton Fabrics as Zirconium Complexes. Text Res J 51: 90-96.

9. Menezes E (2002) Antimicrobial Finishing for Specialty Textiles. Clothesline 5: 96-99.

10. Sun G, Xu X (1981) Durable and Regenerable Antibacterial Finishing of Fabrics: Biocidal properties. Text Chem Color 30: 26-30.

11. Kloos WE, Musselwhite MS (1975) Distribution and Persistence of Staphylococcus and Micrococcus Species and Other Aerobic Bacteria on Human Skin. Appl Microbiol 9: 381-395. 
Citation: Moses JJ, Venkataraman VK (2014) Study of Mechanical and Surface Properties on some Chemical Treated Cotton Fabric by KES-F, SEM and FTIR Analysis. J Textile Sci Eng S2: 004. doi:10.4172/2165-8064.S2-004

12. Vigo TL, Leonas KK (1999) Antimicrobial Activity of Fabrics Containing Crosslinked Polyethylene Glycols. Text Chem Color 1: 42-46.

13. Chung YS, Kuen K, Kim JW (1982) Durable Press and Antimicrobial Finishing of Cotton Fabrics with a Citric Acid and Chitosan Treatment. Text Res J 68: $772-775$

14. Jothi D (2009) Experimental Study on Antimicrobial Activity of Cotton Fabric Treated With Aloe Gel Extract From Aloe Vera Plant for Controlling the Staphylococcusaureus (bacterium). Afr J Microbiol Res 3: 228-232.

15. Chengaiah B, Rao KM, Kumar KM, Alagusundaram M, Chetty CM (2010) Medicinal Importance of Natural Dyes-A Review. Int J Pharm Tech Research 2: 144-154.

16. Anna H, Christian RV (2003) The Potential Use of Organically Grown Dye Plants in Organic Textile Industry. J Sustain Agri 23: 17-40.

17. Ramachandran T, Rajendrakumar K, Rajendran R (2004) Antimicrobial Textiles -An Overview.J Text 84: 42-47.

18. Shukla SR (2000) Advances in Preparatory Process in Cotton, NCUTEProgramme Series, Chemical Preparatory Process in Textiles, IIT, Delhi, India.
19. Trotman ER (1985) Dyeing and Chemical Technology of Textile Fibers (6th edn.). Edward Arnold, London, UK.

20. Mohanty BC, Chandramauti KV, Naik HD (1987) Natural Dyeing Process of India, Published by Calico Museum of Textiles, India.

21. Ryan JJ (1971) Chemical After Treatments of Textile, Editors: Marx H., Wooding N.S. and Atlas S.M, Wiley Inter Science, New York, USA.

22. Talebpour E, Holme I (2006) Effects of Silicone Based Softener on The Easy Care Finished Cotton Fabric. Ind J Fiber Text Res 31: 444-449.

23. Kawabata S, Niwa M (1989) Fabric Performance In Clothing and Clothing Manufacture. J Text Inst 80: 19-50.

24. Gouda M, Hebeish A (2010) Preparation and Evaluation of CuO/Chitosan Nanocomposite for Antibacterial Finishing Cotton Fabric. J Indus Text 39: 203214.

25. John C (2000) Encyclopedia of Analytical Chemistry. Wiley Online Library, USA. 